\title{
Morphophysiological Responses of Olive Plants of the Arbequina Cultivar in Acid Soils
}

\author{
Henrique Bisognin Gallina*, Cristiano Geremias Hellwig, Marcelo Barbosa Malgarim, \\ Paulo Mello-Farias
}

Departamento de Fitotecnia, Universidade Federal de Pelotas, Pelotas, Brasil

Email: ^ikaogallina@hotmail.com

How to cite this paper: Gallina, H.B., Hellwig, C.G., Malgarim, M.B. and MelloFarias, P. (2017) Morphophysiological Responses of Olive Plants of the Arbequina Cultivar in Acid Soils. American Journal of Plant Sciences, 8, 2732-2747.

https://doi.org/10.4236/ajps.2017.811184

Received: August 19, 2017

Accepted: October 17, 2017

Published: October 20, 2017

Copyright $\odot 2017$ by authors and Scientific Research Publishing Inc. This work is licensed under the Creative Commons Attribution International License (CC BY 4.0). http://creativecommons.org/licenses/by/4.0/

\section{Open Access}

\begin{abstract}
The current study aimed to investigate the morphophysiological responses with determinations of the plant height, stem diameter, chlorophyll content, and leaf nutrients of 'Arbequina' olive plant in acid soils. For evaluations of plant height, stem diameter, chlorophyll content, the experimental design was completely randomized arranged in split-plot design. The factor allocated to the main plots was consisted of the time after transplant $(0,30,60,90,120$ and 150 days after transplant-DAT) and, the factor arranged in the subplots was composed by $\mathrm{pH}$ with six levels $2.9 ; 3.1 ; 3.9 ; 4.3 ; 5.0$; and, 6.3 (witness). In determination of leaf nutrient content (nitrogen, phosphorus, potassium, calcium, magnesium, sulfur, copper, zinc, iron, manganese, aluminium and boron) was followed the same experimental design, however, only $\mathrm{pH}$ was tested. Plant height, stem diameter and chlorophyll content (SPAD) are not prejudiced by acidic $\mathrm{pH}$ up to $150 \mathrm{DAT}$. For the different $\mathrm{pH}$ levels tested, the nitrogen, phosphorus, potassium, calcium, magnesium, sulfur, copper, zinc, iron, manganese and boron foliar contents are adequate for the olive crop, except nitrogen at $\mathrm{pH}$ 2.9. The 'Arbequina' olive plants adequately support acidic soils even with accentuated additions in the foliar aluminium content.
\end{abstract}

\section{Keywords}

$\mathrm{pH}$, Olive Tree, Abiotic Stress, Plant Height

\section{Introduction}

The olive tree (Olea europaea L.) is a crop, among the oilseeds, which has gained prominence within the world agricultural chain, concentrating basically on two products, olive oil and table olives. The world production of olives in 2014 was 15.4 million tons, in a cultivated area of 10.3 million hectares. Spain was the 
largest producer (4.6 million tons), followed by Italy (1.9 million tons), Greece and Turkey (1.8 million tons each) and Morocco (1.6 million tons). Together they accounted for $76 \%$ of the world's supply. Alongside, Brazil occupied the thirty-sixth position, with production of 512 tons [1].

However, the yield of olives can be seriously compromised because of climatic changes in areas of their greatest activity, or with need to introduce crop into unfavorable agricultural areas. Although it is a well-adapted plant to withstand relatively high solar radiation, low temperatures, dry and salinity [2]-[7], the cultivation in acid soils is still a challenge to the crop, because it modify both, the growth and the nutritional balance of the plants [8] [9].

According to literature, it is documented that the olive tree is a species with tolerance to salinity [2] [7] [10]. However, when grown on acid soils information on aluminium tolerance is still scarce [11]. These soils comprise acidity ranging from 4.5 to 5.5 [12], high content of organic matter [13] [14], low availability of phosphorus [15], as well as low calcium, magnesium and molybdenum contents [16] and high levels of extractable aluminium and manganese [17]. At $\mathrm{pH} \leq 5.5$, aluminium toxicity is the main stress factor for plants [18] [19], which limits crop production.

In acidic conditions there is an increased of trivalent cation $\left(\mathrm{Al}^{3+}\right)$ [20] [21], which among all species of aluminium, is the more toxic available to the plant [22]. The first and most recognized effect of aluminium toxicity in plants is an inhibition of division and elongation of meristematic cells and, therefore, reduction in the growth of roots [23] [24]. In the toxicity of aluminium, roots are thinner and dark, resulting in lower efficiency on absorption of water and nutrients, this effect is more pronounced in the seedlings than in adult plants [25]. Other effects include reduction of cellular respiration; high rigidity of the cell wall [26]; and, inhibition of photosynthesis [20].

The cultivation of olive orchards is expanding in countries with acid soil problems and aluminium toxicity, as well as in Brazil. The acid soils alter mainly characteristics related to the growth and development of the plants, as in the absorption of chlorophyll pigments necessary for the photosynthesis [20], which results in changes in the plant height, stem diameter and in addition, they alter the nutrients in the leaves of the plants [8] [9]. In this context, the current study aimed to investigate the morphophysiological responses with determinations of the plant height, stem diameter, chlorophyll content, and leaf nutrients of 'Arbequina' olive plant in acid soils.

\section{Materials and Methods}

\subsection{Experimental Design}

The experiment was conducted in a greenhouse on the Phytotecnia Department of the Eliseu Maciel School of Agronomy (FAEM), Federal University of Pelotas (UFPel) located at city of Capão do Leão ( $31^{\circ} 48^{\prime} 13.57^{\prime \prime S}, 52^{\circ} 24^{\prime} 54.18^{\prime \prime} \mathrm{W}$ and 14 m elevation), Rio Grande do Sul, Brazil, from May to November 2016. The climate 
of the region according is of type Cfa, temperate humid with hot summers [27]. During the period of the experiment, minimum temperature was $13.1^{\circ} \mathrm{C}$ and maximum $22.1^{\circ} \mathrm{C}, 84.3 \%$ mean relative humidity and $140.7 \mathrm{~mm}$ mean precipitation [28].

The material used originated from olive-tree plants (eight years) of cv. Arbequina. Each experimental unit was composed of a plastic vase with volumetric capacity of 10 liters, filled with sifted soil and classified as solodic Haplic Eutrophic Planosol, belonging to Pelotas mapping unit [29], with a one year old plant approximately obtained by micropropagation. Were selected plants with the same height, stem diameter and phytosanitary status, free from diseases and pests. The soil used was analyzed for chemical and physical characteristics (Table 1). Olive plants were transplanted to vase in May 2016 and evaluated at 0 , 30, 60, 90, 120 and 150 days after transplantation (DAT). The management and cultural practices were carried out following the technical recommendations of the crop [30].

For evaluations of plant height, stem diameter and chlorophyll content, the experimental design was completely randomized, arranged in split-plot design, with five replications, each replicate being composed of three plants. The factor allocated to the main plots consisted of the time after the transplant, being 0,30 , $60,90,120$ and 150 days after the transplant (DAT), and the factor arranged in the subplots was composed by pH with six levels $2.9 ; 3.1 ; 3.9 ; 4,3 ; 5.0$; and, 6.3 (considered as a witness). For determination of the leaf nutrient content was followed the same experimental design and number of replications, but only the $\mathrm{pH}$ treatment factor was tested, at the same levels described previously.

The soil $\mathrm{pH}$ adjustment on the vases was carried out with $\mathrm{H}_{2} \mathrm{SO}_{4}(0.01 \mathrm{mM})$ from the sampling and analysis of $10 \mathrm{~g}$ of soil. The reading was performed with benchtop pHmeter (Quimis ${ }^{\circledast}$, model Q400AS, São Paulo, Brazil) and Mettler

Table 1. Chemical and physical characteristics of the soil sample before the installation of the experiment.

\begin{tabular}{|c|c|c|c|c|c|c|c|c|c|c|}
\hline \multirow{2}{*}{$\begin{array}{c}\mathrm{pH} \\
\text { Water 1:1 }\end{array}$} & $\mathrm{Ca}^{1} /$ & $\mathrm{Mg}^{1 /}$ & $\mathrm{Al}^{1 /}$ & $\mathrm{H}+\mathrm{Al}$ & $\mathrm{CEC}_{\text {effective }}$ & $\mathrm{CEC}_{\mathrm{pH} 7.0}$ & $\mathrm{~K}$ & \multicolumn{2}{|c|}{ Saturation (\%) } & In 1 c \\
\hline & \multicolumn{7}{|c|}{ - } & $\mathrm{Al}$ & Bases & \\
\hline 6.0 & 4.3 & 4.3 & 0.0 & 1.7 & 8.8 & 10.5 & 0.20 & 0.00 & 84 & 6.8 \\
\hline O.M. (\%) & \multicolumn{2}{|c|}{ Clay $(\%)$} & \multicolumn{2}{|c|}{ Class of clay } & S & \multicolumn{2}{|c|}{ P-Mehlich ${ }^{2} /$} & $\mathrm{K}^{2} /$ & \multicolumn{2}{|r|}{$\mathrm{Fe}(\%)$} \\
\hline 1.24 & \multicolumn{2}{|c|}{15} & \multicolumn{2}{|c|}{4} & 4.5 & \multicolumn{2}{|c|}{16.5} & 79 & \multicolumn{2}{|r|}{0.13} \\
\hline \multirow[t]{2}{*}{$\mathrm{Cu}^{2} /$} & $\mathrm{Zn}^{2}$ & B & & & $\mathrm{Na}^{2} /$ & \multicolumn{5}{|c|}{ Molar relationships } \\
\hline & - & 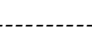 & $m^{3}-$ & 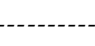 & & $\mathrm{Ca} / \mathrm{l}$ & & $\mathrm{Ca} / \mathrm{K}$ & & $\mathrm{Mg} / \mathrm{K}$ \\
\hline 0.7 & 0.7 & - & & & 10 & 1.0 & & 21.50 & & 21.50 \\
\hline
\end{tabular}

Clay determined by the densimeter method. O.M.: organic matter by wet digestion. ${ }^{1 /}$ Extraction method of $\mathrm{Ca}, \mathrm{Mg}, \mathrm{Al}$ and $\mathrm{Mn}$ of the soil that use $\mathrm{KCl}$ solu-

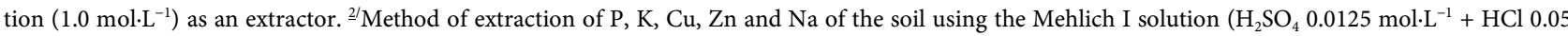
$\mathrm{mol} \cdot \mathrm{L}^{-1}$ ) as an extractor. In all extractions the ratio of soil: extraction solution of 1:10 (sample mass of $5.0 \mathrm{~g}$ and volume of the extracting solution of $50 \mathrm{~mL}$ ) was used. CEC: Cation Exchange Capacity. 
Toledo electrode (Inlab 413) individually form per vase in $10 \mathrm{~g}$ of dry soil, diluted and homogenized in distilled water. The $\mathrm{pH}$ of the experimental units was established at the experiment installation, and weekly one $\mathrm{pH}$ measurement and adjustment were performed according to the determined levels.

\subsection{Measurements of Morphophysiological Responses}

One day after plant transplantation, the first evaluation was performed for plant height, stem diameter and chlorophyll content, who was considered the initial time (zero). Subsequently, these evaluations were performed every 30 days after the transplant date (DAT), totaling six evaluations. Plant height was determined using a millimeter ruler, measuring from $10 \mathrm{~cm}$ of soil height to the highest point of the plant and the results were expressed in centimeters $(\mathrm{cm})$. The stems diameters were measured at $10 \mathrm{~cm}$ from the soil, using a digital caliper (Starret $727)$, and the results were expressed in millimeters $(\mathrm{mm})$. The relative chlorophyll content (SPAD) was determined with the Soil Plant Analysis Development Chlorophyll Meter (SPAD-502, Minolta, Japan) by reading in median part of the leaf, in 30 leaves per experimental unit.

For the determination of leaf nutrient content, leaf collection occurred at's 150 DAT. Each sample was composed of 200 leaves, 50 leaves were collected in each quadrant (north, south, east and west). Two to three leaves were collected per branch, in the middle third of outer branches of the top. The samples were stored in identified paper bags and sent immediately for chemical analysis, which was carried out at the Soil Analysis Laboratory of the Department of Soil of the Federal University of Rio Grande do Sul (UFRGS). The samples were dried at $65^{\circ} \mathrm{C}$ in a kiln with forced air circulation and ground until completely sieved with a $2 \mathrm{~mm}$ mesh. The nutrients determined were nitrogen by the TKN method, by sulfur digestion and distillation (Kjeldahl), with limit of detection of $0.01 \%$ and results expressed as percentage $(\mathrm{m} / \mathrm{m})$, and total phosphorus, potassium, calcium, magnesium and sulfur by wet digestion in extracts of nitric-perchloric acids by optical emission spectrophotometry (ICP-OES) and detection limit of $0.01 \%$, and the results were expressed as percentage $(\mathrm{m} / \mathrm{m})$. The total copper, zinc, iron, manganese and aluminium contents were also quantified by ICP-OES in wet digestion in extracts of nitric-perchloric acids and the results expressed in $\mathrm{mg} \cdot \mathrm{kg}^{-1}$, with a detection limit of $0.3 \mathrm{mg} \cdot \mathrm{kg}^{-1}$ for copper, $1 \mathrm{mg} \cdot \mathrm{kg}^{-1}$ for zinc, $2 \mathrm{mg} \cdot \mathrm{kg}^{-1}$ for iron and manganese, and $10 \mathrm{mg} \cdot \mathrm{kg}^{-1}$ for aluminium. Boron was determined in dry digestion by ICP-OES, with limit of detection of 1 $\mathrm{mg} \cdot \mathrm{kg}^{-1}$ and the results expressed in $\mathrm{mg} \cdot \mathrm{kg}^{-1}$ [31] [32].

\subsection{Statistical Analysis}

The data were analyzed for normality by the Shapiro-Wilk's test; to homoscedasticity by the Hartley's test; and, the independence of was by graphic analysis. Afterwards, data of plant height, stem diameter and chlorophyll content were submitted to the Response Surface Regression procedure (PROC RSREG), with analysis of the effects linear, quadratic and interaction linear of independent 
variables [33]. The fit of the model was based on low residuals; low p-value; low standard deviation; high coefficient of determination $\left(\mathrm{R}^{2}\right)$ and $\mathrm{R}^{2}$ adj. and the lack of fit for the model, which was determined by analysis of variance (ANOVA), using the Response Surface Regression (RSREG) procedure. The lack of fit test is designed to determine whether the selected model is adequate for describing the observed data or whether a more complex model should be used. Statistical testing of the model was done by Fisher's statistical test. The robustness of the model was assessed by the determination coefficient $\left(R^{2}\right)$, and F-test. Then, the second-order polynomial Equation (1) was fitted to the data of the response variables:

$$
y=\beta_{0}+\Sigma \beta_{i} x_{i}+\Sigma \beta_{i i} x_{i}^{2}+\Sigma \beta_{i j} x_{i} x_{j}
$$

where $y$ is the response variable; $x_{i}, x_{j}$ are the input variables, which influence the response variable $\mathrm{y} ; \beta_{0}$ is the intercepto; $\beta_{i}$ is the linear effect; $\beta_{i i}$ is the quadratic effect and $\beta_{i j}$ is the interaction between $x_{i}$ and $x_{j}$.

For optimization an additional canonical rotational analysis was used the response surface, where the levels of the variables $\left(x_{1}, \mathrm{pH} ; x_{2}\right.$, time after transplantation) (within the experimental range) were determined to obtain the response of each dependent variable studied. The optimization of the response functions consisted of the translation of the response function $(y k)$ from the origin into the stationary points $\left(x_{0}\right)$. The response function was maximal when all roots obtained negative values, and minimum when all roots obtained positive values. If one of the roots has showed positive and negative values, a saddle point was characterized [34] [35].

For leaf nutrient content data, after verification of the assumptions, they were submitted to analysis of variance through the F-test ( $\leq \leq 0.05)$. Statistically significant, the $\mathrm{pH}$ effect was evaluated by regression models ( $\mathrm{p} \leq 0.05$ ), as per Equations (2)-(4):

$$
\begin{aligned}
& y=y_{o}+a x \\
& y=y_{o}+a x+b x^{2} \\
& y=y_{o}+a / x+b / x^{2}
\end{aligned}
$$

where: $y=$ response variable; $y_{o}=$ response variable corresponding to the minimum point of the curve; $a=$ estimated maximum value for the response variable; $b=$ slope of the curve; $x=\mathrm{pH}$. The selection of the model was based on the low residue, low p-value, and high $R^{2}$ and $R^{2}$ adj. When no equation adjustment occurred, $\mathrm{pH}$ levels were compared with 95\% confidence intervals, these intervals were plotted on the graph and the differences were considered significant when there was no overlap between the vertical bars.

\section{Results and Discussion}

\subsection{Plant Height, Stem Diameter and Chlorophyll}

The tests of normality, homoscedasticity and the independence of the residue 
showed that data transformation was not necessary. The ANOVA of the regression models indicated that the resulting models were highly significant $(\mathrm{p}<$ 0.05 ) and did not show a lack of significant adjustment. Thus, these models were used to describe the effects of independent variables ( $\mathrm{pH}$ and time after transplant) on plant height, stem diameter and chlorophyll content (SPAD) of 'Arbequina' olive plants (Table 2).

Both the linear and quadratic effect of $\mathrm{pH}$ and the time after transplantation and your interaction were observed for plant height, stem diameter and chlorophyll content (SPAD) (Table 2). The resulting response surface equation described plants height perfectly $\left(R^{2}=0.80\right.$ and $R^{2}$ adj $\left.=0.78\right)$, together with the lack of fit which was not significative $(p=0.49)$ (Table 2 and Figure $1(a))$. The relationship between plant height and independent variables was described by the established response surface model and from the canonical rotational analysis, the stationary point was minimal (Figure 1(a)). By the optimization it was obtained $76.63 \mathrm{~cm}$ of height with $\mathrm{pH}$ of 4.7 in 15.2 days after the transplant.

Plant height showed decreases in all pHs tested in the days following transplantation (up to 60 DAT) (Figure 1(a)). A similar result was obtained in guava,

Table 2. Results of the ANOVA for regression equation of plant height $(\mathrm{cm})$, stem diameter $(\mathrm{mm})$ and chlorophyll content (SPAD) of 'Arbequina' olive plants submitted to different soil $\mathrm{pHs}$ over time after the transplant.

\begin{tabular}{|c|c|c|c|c|c|}
\hline Variable responses & Source & SS & MS & $F$ value & $\operatorname{Pr}>F$ \\
\hline \multirow{6}{*}{ Plant height $(\mathrm{cm})$} & Linear & 13872 & & 23.43 & $<0.0001$ \\
\hline & Quadratic & 1894 & & 3.20 & 0.0415 \\
\hline & Cross-product & 1204 & & 4.07 & 0.0441 \\
\hline & Total model & 16970 & & 11.47 & $<0.0001$ \\
\hline & Lack of fit & 19635 & 654.51 & 0.85 & 0.49 \\
\hline & Pure error & 138137 & 274.63 & & \\
\hline \multirow{6}{*}{ Stem diameter $(\mathrm{mm})$} & Linear & 39.70 & & 21.10 & $<0.0001$ \\
\hline & Quadratic & 22.19 & & 11.80 & $<0.0001$ \\
\hline & Cross-product & 1.18 & & 1.26 & 0.0480 \\
\hline & Total model & 63.07 & & 13.41 & $<0.0001$ \\
\hline & Lack of fit & 22.61 & 0.75 & 0.79 & 0.78 \\
\hline & Pure error & 478.85 & 0.95 & & \\
\hline \multirow{6}{*}{$\begin{array}{l}\text { Chlorophyll content } \\
\text { (SPAD) }\end{array}$} & Linear & 208.94 & & 2.78 & 0.0062 \\
\hline & Quadratic & 393.78 & & 5.24 & 0.0056 \\
\hline & Cross-product & 106.95 & & 2.85 & 0.0092 \\
\hline & Total model & 709.67 & & 3.78 & 0.0023 \\
\hline & Lack of fit & 3732 & 124.42 & 0.84 & 0.51 \\
\hline & Pure error & 16258 & 32.39 & & \\
\hline
\end{tabular}

SS, sum of squares; MS, mean square. 
(a)

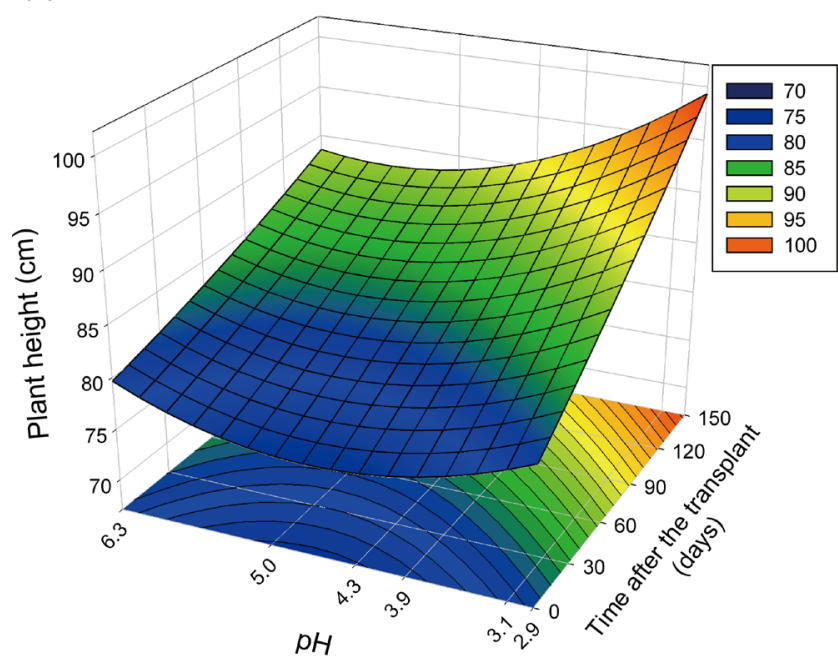

$y=108.27-13.99 x_{1}+0.17 x_{2}+1.50 x_{1}^{2}+0.0001 x_{2}^{2}-0.02 x_{1} x_{2}$ (b)

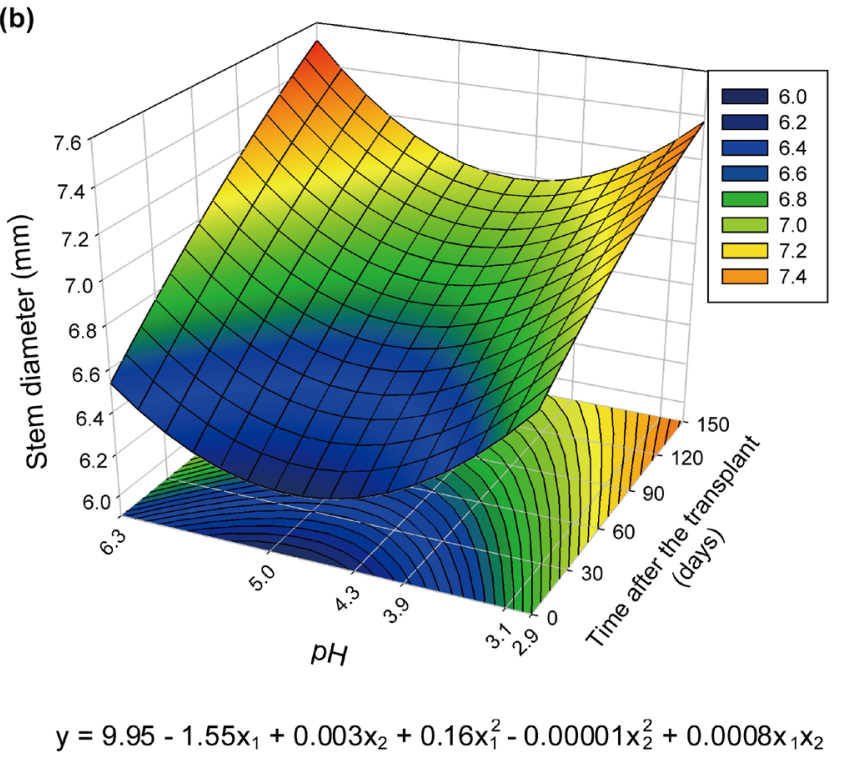

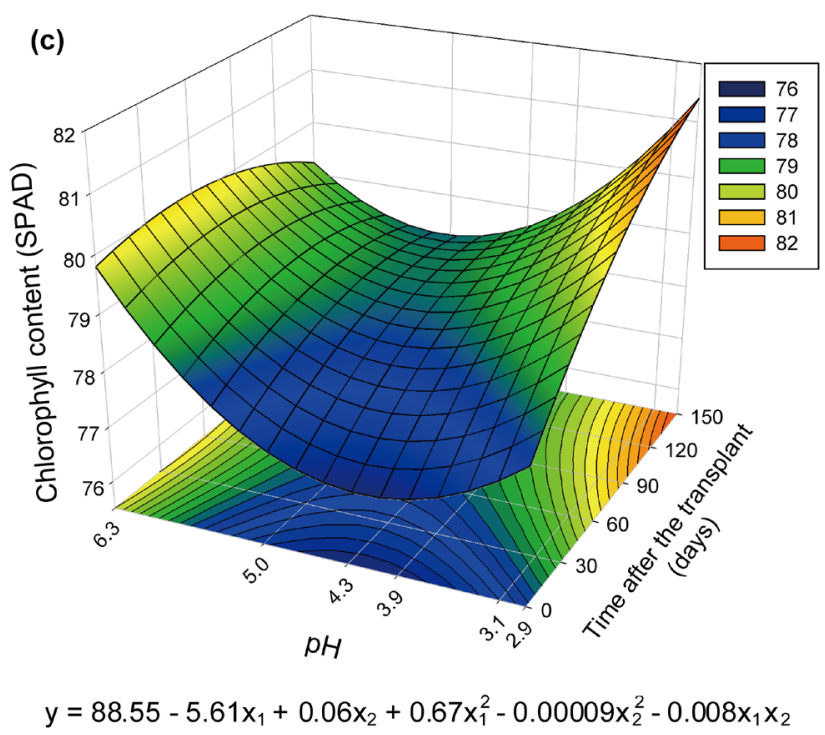

Figure 1. Plant height ( $\mathrm{cm})(\mathrm{a})$, stem diameter $(\mathrm{mm})(\mathrm{b})$ and chlorophyll content (SPAD) (c) of 'Arbequina' olive plants submitted to different soil $\mathrm{pHs}$ over time after the transplant.

where the increase of aluminium doses resulted in a reduction in the height of the seedlings evaluated at 30 days [36]. However, in the extremely acidic pHs (3.1 and 2.9), which were responsible for the higher leaf aluminium contents (Figure 2(e)), the plant height values were higher than those verified at the initial $\mathrm{pH}$ (6.3). Thus, 'Arbequina' olive plants tolerated acidic $\mathrm{pHs}$ and these did not interfered with growth.

The stem diameter $\left(R^{2}=0.78\right.$ and $R^{2}$ adj $\left.=0.76\right)$ was explained by the response surface equation and the test for the lack of fit was not significative $(\mathrm{p}=0.78)$, confirming that response surface equation adequately delineated the data (Table 2 and Figure 1(b)). For the stem diameter, the canonical and stationary point 

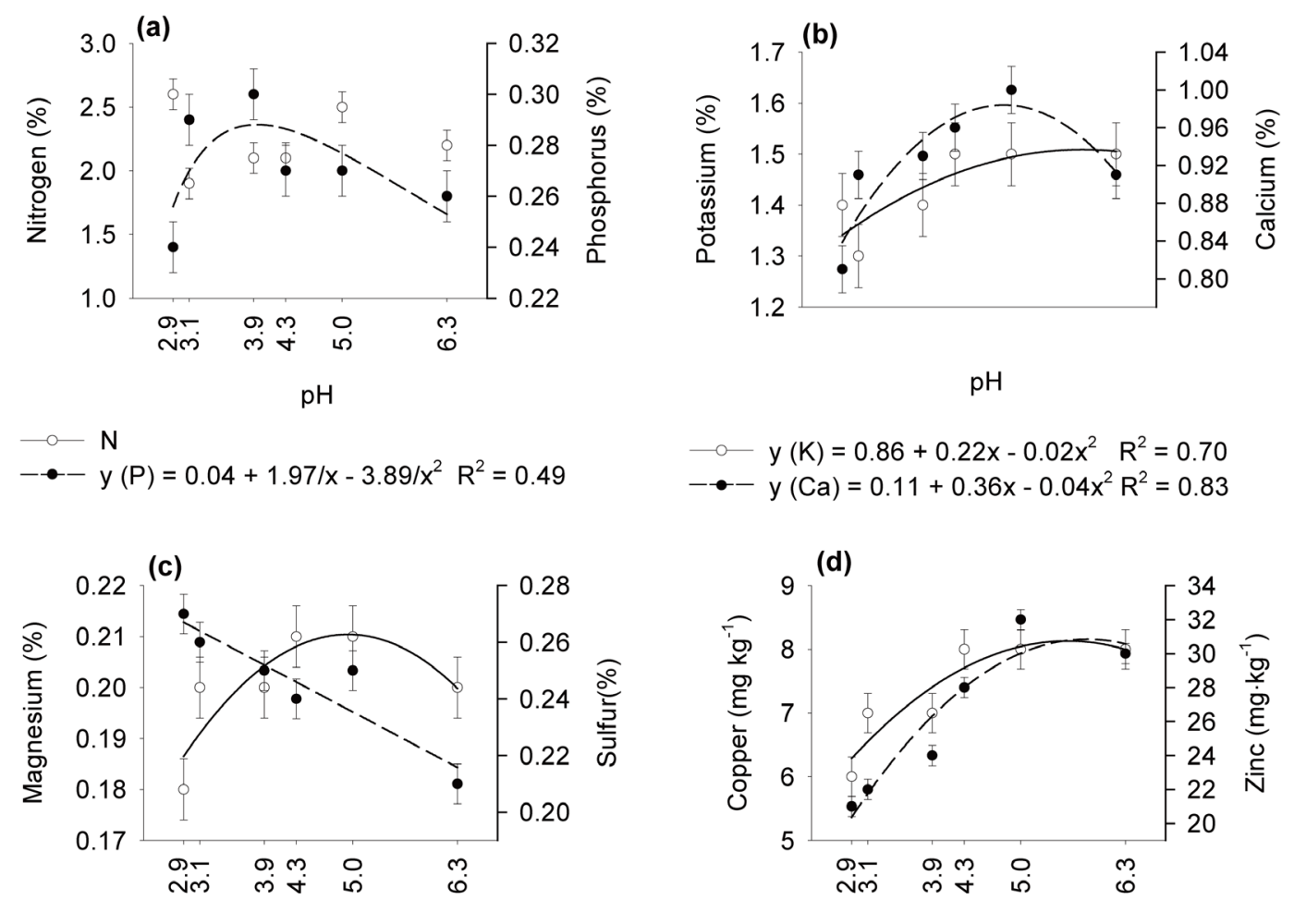

$\mathrm{pH}$

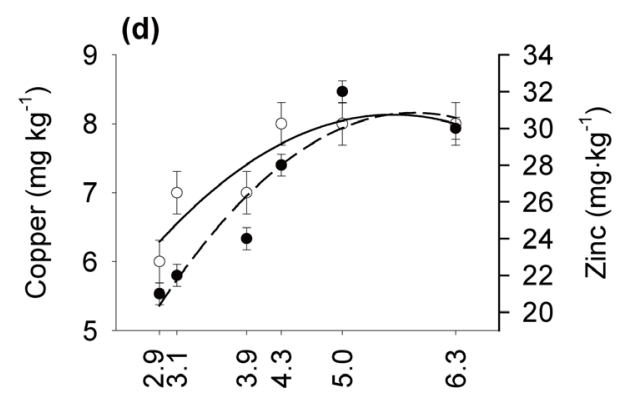

$\mathrm{pH}$

$\begin{aligned} \longrightarrow-y(M g) & =0.07+0.06 x-0.006 x^{2} R^{2}=0.76 \\ --y(S)=0.31-0.02 x & R^{2}=0.85\end{aligned}$

$\begin{array}{ll}\longrightarrow y(C u)=0.14+2.86 x-0.26 x^{2} & R^{2}=0.84 \\ --y(Z n)=-10.84+14.33 x-1.23 x^{2} & R^{2}=0.90\end{array}$

(e)

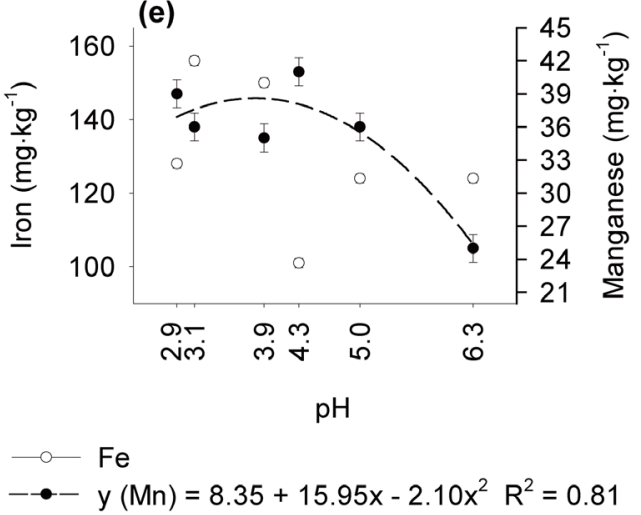

(f)

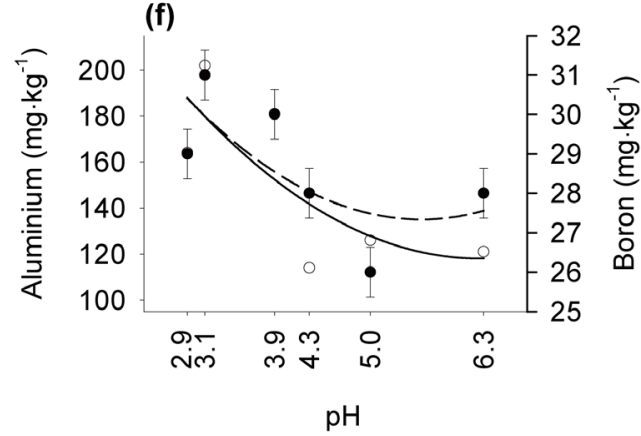

$\multimap y(A l)=361.45-77.91 x+6.24 x^{2} R^{2}=0.60$

$--y(B)=40.65-4.77 x+0.43 x^{2} \quad R^{2}=0.51$

Figure 2. Contents of nitrogen and phosphorus (a); potassium and calcium (b); magnesium and sulfur (c); copper and zinc (d); iron and manganese (e); and, aluminium and boron (f) on olive leaf 'Arbequina' submitted to different pHs. (Vertical bars represent confidence intervals 95\%).

analysis indicated the saddle point (mixed signals of all eigenvalues) as a stationary point, suggesting that the movement away from these points caused increases or decreases in the response, depending on the direction of movement. By mathematical optimization, the optimal conditions were $\mathrm{pH} 5.7$ and time after transplantation of 107 days, obtaining $7.17 \mathrm{~mm}$ of stem diameter.

At pHs 5.0; 4.3; and, 3.9 the stems diameters showed decreases up to 90 DAT. However, at pHs 3.1 and 2.9 the diameter increased and these values approached 
to the initial $\mathrm{pH}$ values (6.3) at both 120 and 150 DAT (Figure 1(b)). These results contradict those obtained in guava tree, where there was a reduction in stem diameter at 110 days [36].

The $\mathrm{p}$-value of the model $(<0.0023)$ and the lack of fit not significative $(\mathrm{p}=$ 0.51 ) indicated that the experimental data obtained adjusted for the model established for the chlorophyll content (SPAD). The resulting regression equation had coefficient of determination $\left(\mathrm{R}^{2}\right)$ of 0.83 and $\mathrm{R}^{2}$ adj. of 0.80 , indicated that $83 \%$ of the total variation was explained by the model (Table 2 and Figure $1(\mathrm{c})$ ). The canonical rotational analysis and the stationary point also indicated as stationary point the saddle point for chlorophyll content (SPAD) (Figure 1(c)). By mathematical optimization, the optimum conditions were $4.8 \mathrm{pH}$ at 118.8 DAT. Under these conditions, the chlorophyll content (SPAD) was 78.45.

The highest reductions in chlorophyll content were observed on the initial days after transplantation at $\mathrm{pH} 4.3$ and 3.9 (Figure $1(\mathrm{c})$ ). This suggests that the occurrence of chlorophyll degradation and early senescence, probably due to the harmful effects of reactive oxygen species on chloroplasts [9] [37].

The high concentrations of aluminium in the soil hinder the development of the plant at the physiological and biochemical level, altering the photosynthetic rate, the total chlorophyll content and also inhibit the transport of electrons in the PSII [37] [38]. This was not confirmed by measurements of the SPAD index, widely used as a non-destructive estimate of chlorophyll content. In the last evaluation (150 DAT), which coincides with the nutritional evaluation, high levels of aluminium were observed in the leaves at pHs 3.1 and 2.9 (Figure 2(e)), while the average values obtained for chlorophyll at these $\mathrm{pHs}$ were higher than $\mathrm{pH}$ 6.3. The plants were able to recover the chlorophyll content under high stress in acid soil, exceeding the initial value of chlorophyll, which shows that the 'Arbequina' olive plants were possibly tolerant to the action of aluminium [11].

\subsection{Nitrogen, Phosphorus, Potassium, Calcium, Magnesium, Sulfur, Copper, Zinc, Iron, Manganese, Aluminium and Boron}

In all nutrients was observed significance for the $\mathrm{pH}$ effect (Figure 2). For the nitrogen data it was not possible to adjust regression models and the highest content was verified at $\mathrm{pH} 2.9$ with a performance equal to $\mathrm{pH}$ 5.0. However, pH's 4.3; 3.9; and, 3.1 did not differ from each other (Figure 2(a)). No large changes in nitrogen content were observed, in the $\mathrm{pH} 6.3$ the contents of nitrogen was $2.2 \%$ and extreme acid $(\mathrm{pH} 2.9)$ was $2.6 \%$. The Arbequina olive tree plants tolerate appropriately the acidic $\mathrm{pHs}$, and in none of the evaluated $\mathrm{pH}$ did indicate that the leaf nitrogen concentration fall below the threshold of deficiency (1.4\%) [39] [40] [41]. However, at pH 2.9 as the mean value was $2.6 \%$, this value is already considered to be toxic to the plant [42] [43]. Generally, elements such as potassium, boron, nitrogen and manganese are required by the plant in larger quantities at the time of flowering and fruiting [44], moment who is not applicable in the study. As nitrogen is integral component of proteins, nucleic acids and many other organic structures in living cells [45], this explains its 
abundance found in the leaves of this study.

The second-order inverse polynomial regression model was adjusted for the total phosphorus content $(\mathrm{F}=5.3189, \mathrm{p}=0.018$ ), with observed increases of 9.3; 12.9 ; 13.6 ; and, $6.3 \%$ for $\mathrm{pHs} 5.0 ; 4.3 ; 3.9$; and, 3.1 , respectively when compared to the control ( $\mathrm{pH}$ 6.3) (Figure 2(a)). The foliar phosphorus content was adequate to the sufficiency range indicated for the culture of 0.1 to $0.3 \%$ [46], revealing good capacity of absorption of the nutrient, since, regardless of the $\mathrm{pH}$ used and despite of mean value initial in soil, these maintained medium to high levels of phosphorus in foliar tissue. In the olive tree, phosphorus is removed in small quantities for fruit production and under pruning effect, compared to other macronutrients [47], and the efficiency of absorption is also very low [48].

For potassium $(\mathrm{F}=3.4643, \mathrm{p}=0.05)$ the quadratic polynomial regression model was fitted (Figure 2(b)). When olive plants 'Arbequina' were subjected to acidic pHs 3.9 and 3.1 occurred decrease in potassium concentrations of 2.6 and $7.0 \%$, respectively, compared to $\mathrm{pH} 6.3$, and the maximum estimated was $1.47 \%$ potassium at $\mathrm{pH}$ 5.5. The potassium showed adequate concentration $(>0.8 \%)$ [42] [43] for all $\mathrm{pHs}$ tested, reaching $1.5 \%$ between $\mathrm{pH} 6.3$ to 4.3 but not exceeding to $1.65 \%$, which would be toxic to the plant. Although it is documented that potassium many times represents a nutritional problem in olive orchards [44] [49], even with decreases in the contents, the $\mathrm{pH}$ range tested did not represent a deficiency for the plant and without the need to apply high fertilizer rates.

Calcium $(\mathrm{F}=12.1839, \mathrm{p}=0.0007)$ showed quadratic behavior (Figure 2(b)) and when the 'Arbequina' olive plants were submitted to pHs 3.9 and 3.1 showed increases of 14.6 and $6.5 \%$ in calcium contents, respectively, when compared to $\mathrm{pH}$ 6.3. By deriving the mathematical model, the maximum estimated was $0.92 \%$ of calcium with $\mathrm{pH}$ 4.5. Even with register of the increase in calcium content with the $\mathrm{pH}$ reduction, the mean values still remained within the range considered ideal for the crop, which recommends as deficiency values lower than $0.6 \%$, adequate (optimal) between $1 \%-1.43 \%$ and toxic when higher than $3.5 \%$ [42] [43].

Studies have shown that aluminium directly interferes with various channel proteins in the plasma membrane, thereby reducing the absorption of mono and divalent cations, such as potassium and calcium [50] [51]. Aluminium-triggered stress was reported to reduce calcium through three mechanisms: (1) inhibition of calcium transport by simplastic pathway by aluminium, (2) disruption of calcium homeostasis in aluminium-induced cytoplasm, and (3) displacement of calcium by aluminium in apoplastic pathway [52] [53]. In contrast to these reports, in this study (Figure $1(\mathrm{~b})$ and Figure $1(\mathrm{f})$ ) only a reduction in calcium content at extremely acidic $\mathrm{pH}$ (2.9) occurred, confirming that the 'Arbequina' olive plants were able to withstand the other $\mathrm{pHs}$ tested and that even with increases in aluminium content, did not reduce the absorption of this nutrient.

This indicates that another mechanism is involved in mitigating the effect of aluminium toxicity, for example, sequestration of this toxic element into 
metabolically less sensitive cell compartments such as vacuoles or activation of genes involved in defense antioxidant mechanisms [38] [54] [55] [56].

The data concerning the percentage of magnesium generated in olive leaves with the $\mathrm{pHs}$ studied were adjusted to the quadratic polynomial regression equation $(F=6.2469, \mathrm{p}=0.0106)$, obtaining a coefficient of determination $\left(\mathrm{R}^{2}\right)$ of 0.76. Plants maintained at $\mathrm{pH} 5.0$ generated the highest percentage of magnesium, increasing by $4.8 \%$ when compared to $\mathrm{pH}$ 6.3. So much so that the maximum estimated value was $0.22 \%$ of magnesium at this $\mathrm{pH}$. Already, the second highest increase percentage (3.4\%) was in the $\mathrm{pH} 4.3$, also in relation to $\mathrm{pH} 6.3$ (Figure 2(c)). In all tested $\mathrm{pH}$, magnesium levels exceeded the range considered adequate $(0.1$ to $0.16 \%)$, but even so, the values obtained were not considered to be toxic because they remained below $0.69 \%$ [42] [43].

With the $\mathrm{pH}$ reduction the sulfur content increased and in the studied range (6.3 to 2.9) this response was linear $(F=23.4225, \mathrm{p}=0.0084)$, with $\mathrm{R}^{2}$ of 0.85 , demonstrating appropriate adjustment of the data to established model (Figure 2 (c)) with a $37 \%$ increase in sulfur content when comparing the $\mathrm{pH} 2.9$ with the initial one (6.3). As with magnesium, the mean values obtained for sulfur exceed the range considered adequate $(0.08 \%$ to $0.16 \%)$ and at $\mathrm{pH} 2.9$ the sulfur content was $0.27 \%$, close to the toxicity range for crop (>0.32\%) [42] [43].

For copper $(\mathrm{F}=4.6302, \mathrm{p}=0.0272)$ and $\operatorname{zinc}(\mathrm{F}=13.5331, \mathrm{p}=0.0315)$ were fitted squared polynomial regression models (Figure $2(\mathrm{~d})$ ). From the extremely acidic soil with pH 3.1 and 2.9, decreases of 17.0 and $20.3 \%$ were observed in the copper contents and, 28.9 and $33.5 \%$ for zinc, respectively, when both were compared to $\mathrm{pH}$ 6.3. By deriving the equations, the estimated maximum value was $8.0 \mathrm{mg} \cdot \mathrm{kg}^{-1}$ copper at $\mathrm{pH} 5.5$ and $30.9 \mathrm{mg} \cdot \mathrm{kg}^{-1}$ zinc at $\mathrm{pH} 5.8$. The leaf nutrient contents of the 'Arbequina' olive plants remained inside of range suitable for copper ( 4 to $9 \mathrm{mg} \cdot \mathrm{kg}^{-1}$ ), whereas for zinc the values exceeded sufficiency (10 to $\left.24 \mathrm{mg} \cdot \mathrm{kg}^{-1}\right)$, but were not considered toxic $\left(>84 \mathrm{mg} \cdot \mathrm{kg}^{-1}\right)$ for the plant [42] [43].

For iron data it was not possible to adjust regression models, and the highest content was found at $\mathrm{pH} 3.1\left(156 \mathrm{mg} \cdot \mathrm{kg}^{-1}\right)$ and lower at $\mathrm{pH} 4.3\left(101 \mathrm{mg} \cdot \mathrm{kg}^{-1}\right)$, which both of these differed from others. The records in the literature indicate as adequate values between 90 to $124 \mathrm{mg} \cdot \mathrm{kg}^{-1}$ of iron and as toxicity values greater than $460 \mathrm{mg} \cdot \mathrm{kg}^{-1}$. During the reduction of $\mathrm{pH}$, there were increases in the iron content but did not reach to levels considered toxic [42] [43]. Also, it is reported that the olive plants is tolerant to iron chlorosis [46].

While the manganese response in the $\mathrm{pH}$ ranges tested was represented by a quadratic polynomial regression model $(\mathrm{F}=28.6551, \mathrm{p}<0.0001)$ (Figure 2(e)), with high percentages of increase from the reduction of $\mathrm{pH}$, of $39.7 ; 49.5 ; 51.5$; $47.6 ; 44.9 \%$ to $5.0 ; 4.3 ; 3.9 ; 3.1$; and 2.9 , respectively, when compared to the initial pH. The increase in manganese levels in leaves is also explained by the influence of soil $\mathrm{pH}$, since the availability of this nutrient is increased at lower $\mathrm{pH}$ [57]. However, even with increased manganese levels, levels remained close to indicated sufficiency for the crop (20 to $36 \mathrm{mg} \cdot \mathrm{kg}^{-1}$ ) at all $\mathrm{pHs}$ tested [42] [43]. 
Aluminium contents also characterized quadratic behavior with adequate adjustment of the data to the established model $\left(\mathrm{F}=10.9869, \mathrm{p}=0.0012\right.$ and $\mathrm{R}^{2}=$ 0.60 ) (Figure $2(\mathrm{f})$ ). Plants exposed to $\mathrm{pHs} 5.0 ; 3.9 ; 3.1$; and 2.9 obtained increases in aluminium content of $13.1 ; 46.7 ; 84.1 ; 95.1 \%$, when compared to $\mathrm{pH} 6.3$. Aluminium-toxicity is an important stress factor for plants [18], limiting plant growth, development and the subsequent performance of commercial crops [26] in various parts of the world with acidified soils. In this study, the decrease of the $\mathrm{pH}$ levels and the increase of the concentration of aluminium, modified the concentrations of nitrogen, phosphorus, potassium, calcium, magnesium, manganese and zinc in the leaves. Therefore, excessive accumulation of aluminium in the leaves did not reduce the absorption, translocation and accumulation of these nutrients in the tissues of the plants and, therefore, was not responsible for imbalances and mineral deficiencies, as well as did not occur reduction of plant growth, contrary to the results obtained by Rouphael et al. [58]. This behavior raises the possibility that the cultivar 'Arbequina' is tolerant to aluminium [11].

For the boron data $(\mathrm{F}=5.0436, \mathrm{p}=0.0211)$, the quadratic polynomial regression model (Figure 2(f)) was adjusted, with higher increases, of 8.4 and 10.0\% verified for pHs 3.1 and 2.9, respectively, when confronted at $\mathrm{pH} 6.3$. Boron foliar content was adequate for the crop sufficiency (19 to $150 \mathrm{mg} \cdot \mathrm{kg}^{-1}$ ) at all $\mathrm{pHs}$ tested [42] [43].

\section{Conclusion}

The growth of 'Arbequina' olive plants, evaluated by plant height, stem diameter and chlorophyll content (SPAD), is not prejudiced by acidic pH up to 150 DAT. For the different $\mathrm{pH}$ levels tested, the nitrogen, phosphorus, potassium, calcium, magnesium, sulfur, copper, zinc, iron, manganese and boron foliar contents are adequate for the olive crop, except nitrogen at $\mathrm{pH}$ 2.9. The 'Arbequina' olive plants adequately support acidic soils even with accentuated additions in the foliar aluminium content.

\section{Acknowledgements}

The authors express their gratitude to the Coordenação de Aperfeiçoamento de Pessoal de Nível Superior (CAPES).

\section{Conflicts of Interest}

There are no conflicts of interest in present study.

\section{References}

[1] FAO—Food and Agriculture Organization. http://www.fao.org/faostat

[2] Gucci, R. and Tattini, M. (1997) Salinity Tolerance in Olive. Horticultural Reviews, 21, 177-213. https://doi.org/10.1002/9780470650660.ch6

[3] D’andria, R., Lavini, A., Morelli, G., Sebastiani, L. and Tognetti, R. (2009) Physiological and Productive Responses of Olea europaea L. Cultivars Frantoio and Leccino to a Regulated Deficit Irrigation Regime. Plant Biosystems, 143, 222-231. 
https://doi.org/10.1080/11263500802710085

[4] Malik, N.S.A. and Bradford, J.M. (2009) Inhibition of Flowering in "Arbequina" Olives from Chilling at Lower Temperatures. Journal of Food Agriculture and Environment, 7, 429-431.

[5] Sebastiani, L. (2011) Physiological Response of Olive (Olea europaea L.) to Water Deficit: An Overview. Acta Horticulturae, 888, 137-147. https://doi.org/10.17660/ActaHortic.2011.888.14

[6] Fernández, J.E. (2014) Understanding Olive Adaptation to Abiotic Stresses as a Tool to Increase Crop Performance. Environmental and Experimental Botany, 103, 158-179. https://doi.org/10.1016/j.envexpbot.2013.12.003

[7] Rossi, L., Francini, A., Minnocci, A. and Sebastiani, L. (2015) Salt Stress Modifies Apoplastic Barriers in Olive (Olea europaea L.): A Comparison between a Salt-Tolerant and a Salt-Sensitive Cultivar. Scientia Horticulturae, 192, 38-46. https://doi.org/10.1016/j.scienta.2015.05.023

[8] Pécsváradi, A., Nagy, Z., Varga, A., Vashegyi, A., Labádi, I., Galbács, G. and Zsoldos, F. (2009) Chloroplastic Glutamine Synthetase Is Activated by Direct Binding of Aluminium. Physiologia Plantarum, 135, 43-50. https://doi.org/10.1111/j.1399-3054.2008.01167.x

[9] Seguel, A., Cumming, J.R., Klugh-Stewart, K., Cornejo, P. and Borie, F. (2013) The Role of Arbuscular Mycorrhizas in Decreasing Aluminium Phototoxicity in Acidic soils: A Review. Mycorrhiza, 23, 167-183.

https://doi.org/10.1007/s00572-013-0479-x

[10] Pandolfi, C., Bazihizina, N., Giordano, C., Mancuso, S. and Azzarello, E. (2017) Salt Acclimation Process: A Comparison between a Sensitive and a Tolerant Olea europaea Cultivar. Tree Physiology, 37, 380-388.

[11] Setotaw, T.A., Nunes, C.F., Souza, C.S., Ribeiro, A.P., Freitas, G.F., Amorim, D.A., Santos, D.N., Pasqual, M., Ferreira, J.L. and Cançado, G.M.A. (2015) Assessment of tolerance to Aluminum Toxicity in Olive (Olea europaea) Based on Root Growth and Organic Acid $\mathrm{Al}^{3+}$ Exclusion Mechanism. Australian Journal of Crop Science, 9, 264-270.

[12] Samac, D.A. and Tesfaye, M. (2003) Plant Improvement for Tolerance to Aluminum in Acid Soils-A Review. Plant Cell, Tissue and Organ Culture, 75, 189-207. https://doi.org/10.1023/A:1025843829545

[13] Mora, M.L., Cartes, P., Demanet, R. and Cornforth, I.S. (2002) Effects of Lime and Gypsum on Pasture Growth and Composition on an Acid Andisol in Chile, South America. Communications in Soil Science and Plant Analysis, 33, 2069-2081. https://doi.org/10.1081/CSS-120005749

[14] Takasu, E., Yamada, F., Shimada, N., Kumagai, N., Hirabayashi, T. and Saigusa, M. (2006) Effect of Phosphogypsum Application on the Chemical Properties of Andosols, and the Growth and Ca Uptake of Melon Seedlings. Soil Science \& Plant Nutrition, 52, 760-768. https://doi.org/10.1111/j.1747-0765.2006.00093.x

[15] Mora, M.L., Cartes, P., Nuñez, P., Salazar, M. and Demanet, R. (2007) Movement of $\mathrm{NO}_{3}^{-}-\mathrm{N}$ and $\mathrm{NH}_{4}^{+}-\mathrm{N}$ in an Andisol and Its Influence on Ryegrass Production in a Short Term Study. Revista de la Ciencia del Suelo y Nutrición Vegetal, 7, 46-64. https://doi.org/10.4067/S0718-27912007000200005

[16] Kleber, M. and Jahn, R. (2007) Andosols and Soils with Andic Properties in the German soil Taxonomy. Journal of Plant Nutrition and Soil Science, 170, 317-328. https://doi.org/10.1002/jpln.200521851 
[17] Toma, M. and Saigusa, M. (1997) Effects of Phosphogypsum on Ameliorating Strongly Acid Nonallophanic Andosols. Plant and Soil, 192, 49-55. https://doi.org/10.1023/A:1004258629525

[18] Poschenrieder, C., Gunsé, B., Corrales, I. and Barceló, J. (2008) A Glance into Aluminum Toxicity and Resistance in Plants. Science of the Total Environment, 400, 356-368. https://doi.org/10.1023/A:1004258629525

[19] Ryan, P.R. and Delhaize, E. (2010) The Convergent Evolution of Aluminium Resistance in Plants Exploits a Convenient Currency. Functional Plant Biology, 37, 275-284. https://doi.org/10.1071/FP09261

[20] Lidon, F. and Barreiro, M. (2002) An Overview into Aluminum Toxicity in Maize. Bulgarian Journal of Plant Physiology, 28, 96-112.

[21] Kochian, L.V., Pineros, M.A. and Hoekenga, O.A. (2005) The Physiology, Genetics and Molecular Biology of Plant Aluminum Resistance and Toxicity. Plant Soil, 274, 175-195. https://doi.org/10.1007/s11104-004-1158-7

[22] Hoshino, A.A., Boni, T.A., Prioli, J.A., Bravo, J.P. and Priori, S.M.A.P. (2000) Changes Caused by Aluminum in Protein and Carbohydrate Contents in the Apex of Maize Seminal Roots. Acta Scientiarum, 22, 877-882.

[23] Panda, S.K., Singha, L.B. and Khan, M.H. (2003) Does Aluminium Phytotoxicity Induce Oxidative Stress in Greengram (Vigna radiata)? Bulgarian Journal of Plant Physiology, 29, 77-86.

[24] Mora, M.L., Alfaro, M.A., Jarvis, S.C., Demanet, R. and Cartes, P. (2006) Soil Aluminum Availability in Andisols of Southern Chile and Its Effect on Forage Production and Animal Metabolism. Soil Use and Management, 22, 95-101. https://doi.org/10.1111/j.1475-2743.2006.00011.x

[25] Foy, C.D., Chaney, R.L. and White, M.C. (1978) The Physiology of Metal Toxicity in Plants. Annual Review of Plant Physiology, 29, 511-566. https://doi.org/10.1146/annurev.pp.29.060178.002455

[26] Wang, J.P., Harsh, R., Guo-Ping, Z., Neville, M. and Zhou, M.X. (2006) Aluminium Tolerance in Barley (Hordeum vulgare L.): Physiological Mechanisms, Genetics and Screening Methods. Journal of Zhejiang University SCIENCE B, 7, 769-787. https://doi.org/10.1631/jzus.2006.B0769

[27] Köppen, W. and Geiger, R. (1928) Klimate der Erde. [Climates of the Earth.] Gotha, Verlag Justus Perthes. Wall-map 150x200cm.

[28] INMET-Instituto Nacional de Meteorologia (2017). http://www.inmet.gov.br

[29] Embrapa (2006) Centro Nacional de Pesquisa do Solo (CNPS). Sistema brasileiro de classificação de solos. [Brazilian System of Soil Classification.] 2nd Edition, Embrapa Solos, Rio de Janeiro, 306.

[30] Coutinho, E.F., Jorge, R.O., Haerter, J.A. and Costa, V.B. (2015) Oliveira: aspectos técnicos e cultivo no sul do Brasil. [Olive Tree: Technical Aspects and Cultivation in Southern Brazil.] Embrapa, Brasília, 181.

[31] Tedesco, M.J., Gianello, C., Bissani, C., Bohnen, H. and Volkweiss, S.J. (1995) Análise de solo, plantas e outros materiais. [Analysis of soil, plants and other materials.] 2nd Edition, Departamento de Solos da Universidade Federal do Rio Grande do Sul, Porto Alegre, 174.

[32] Silva, F.C. (2009) Manual de análises químicas de solos, plantas e fertilizantes. [Handbook of Chemical Analyzes of Soils, Plants and Fertilizers.] 2nd Edition, Embrapa, Brasília, 627. 
[33] Freund, R.J. and Littell, R.C. (1991) SAS System for Regression. SAS Institute Inc., North Carolina, 127-150.

[34] Myers, R.H. (1971) Response Surface Methodology. Allyn and Bacon, Boston.

[35] Khuri, A.I. and Cornell, J.A. (1989) Response Surfaces: Designs and Analyses. Marcel Dekker, New York.

[36] Salvador, J.O., Moreira, A., Malavolta, E. and Cabral, C.P. (2000) Influência do alumínio no crescimento e na acumulação de nutrientes em mudas de goiabeira. [Influence of Aluminium on Growth and Nutrient Accumulation in Guava Seedlings.] Revista Brasileira de Ciência do Solo, 24, 787-796. https://doi.org/10.1590/S0100-06832000000400011

[37] Chen, L.S. (2006) Physiological Responses and Tolerance of Plant Shoot to Aluminium Toxicity. Journal of Plant Physiology and Molecular Biology, 32, 143-155.

[38] Inostroza-Blancheteau, C., Rengel, Z., Alberdi, M., de la Luz Mora, M., Aquea, F., Arce-Johnson, P. and Reyes-Díaz, M. (2012) Molecular and Physiological Strategies to Increase Aluminum Resistance in Plants. Molecular Biology Reports, 39, 2069-2079. https://doi.org/10.1007/s11033-011-0954-4

[39] Fernández-Escobar, R., Marin, L., Sánchez-Zamora, M.A., García-Novelo, J.M., Molina-Soria, C. and Parra, M.A. (2009) Long-Term Effects of N Fertilization on Cropping and Growth of Olive Trees and on N Accumulation in Soil Profile. European Journal of Agronomy, 31, 223-232. https://doi.org/10.1016/j.eja.2009.08.001

[40] Fernández-Escobar, R. (2011) Use and Abuse of Nitrogen in Olive Fertilization. Acta Horticulturae, 888, 249-258. https://doi.org/10.17660/ActaHortic.2011.888.28

[41] Freeman, M., Uriu, K. and Hartmann, T. (2005) Diagnosing and Correcting Nutrient Problems. In: Olive Production Manual, 2nd Edition, University of California, Agriculture and Natural Resources, Oakland, California, 83-92.

[42] Connell, J.H. and Vossen, P.M. (2007) Organic Olive Orchard Nutrition. In: Vossen, P.M., Ed., Organic Olive Production Manual, Publication 3505, University of California, Oakland, California, 37-43.

[43] Kailis, S. and Harris, D. (2007) Producing Table Olives. Landlinks Press, Collingwood, Vic., 328.

[44] Fernández-Escobar, R. (2008) Fertilización. In: Barranco, D., Fernández-Escobar, R. and Rallo, L., Eds., El Cultivo del Olivo, 6th Edition, Mundi-Prensa, Madri, 297-362.

[45] Scherer, H.W. and Mengel, K. (2007) Ullmann's Agrochemicals. Fertilizers, 3. Wiley, V.C.H., Verlag, GmbH and Co, KGaA, Weinheim.

[46] Rotundo, A., Lombardo, N., Marone, E. and Fiorino, P. (2003) La nutrizione minerale e le concimazioni. [Mineral Nutrition and Fertilization.] In: FIorino, P., Ed., Olea trattato di olivicoltura, Edagricole, Milano, 349-363.

[47] Fernández-Escobar, R., Sánchez-Zamora, M.A., García-Novelo, J.M. and Molina-Soria, C. (2015) Nutrient Removal from Olive Trees by Fruit Yield and Pruning. HortScience, 50, 474-478.

[48] Jimenez-Moreno, M.J. and Fernandez-Escobar, R. (2016) Response of Young Olive Plants (Olea europaea) to Phosphorus Application. HortScience, 51, 1167-1170. https://doi.org/10.21273/HORTSCI11032-16

[49] Freeman, M. and Carlson, R.M. (2005) Mineral Nutrient Availability. In: Sibbett, G.S. and Ferguson, L., Eds., Olive Production Manual, 3353, 2nd Edition, University of California Publication, Oakland, CA, 75-82.

[50] Gassmann, W. and Schroeder, J.I. (1994) Inward-Rectifying $\mathrm{K}^{+}$Channels in Root Hairs of Wheat: A Mechanism for Aluminum-Sensitive Low-Affinity $\mathrm{K}^{+}$Uptake and Membrane Potential Control. Plant Physiology, 105, 1399-1408. 
https://doi.org/10.1104/pp.105.4.1399

[51] Piñeros, M. and Tester, M. (1995) Characterization of a Voltage-Dependent $\mathrm{Ca}^{2+}$ Selective Channel from Wheat Roots. Planta, 195, 478-488.

https://doi.org/10.1007/BF00195704

[52] Delhaize, E. and Ryan, P.R. (1995) Aluminium Toxicity and Tolerance in Plants. Plant Physiology, 107, 315-321. https://doi.org/10.1104/pp.107.2.315

[53] Kochian, L.V. (1995) Cellular Mechanisms of Aluminum Toxicity and Resistance in Plants. Annual Review of Plant Physiology and Plant Molecular Biology, 46, 237-260. https://doi.org/10.1146/annurev.pp.46.060195.001321

[54] Barceló, J. and Poscheinrieder, C. (2002) Fast Root Growth Responses, Root Exudates, and Internal Detoxification as Clues to the Mechanisms of Aluminium Toxicity and Resistance: A Review. Environmental and Experimental Botany, 48, 75-92. https://doi.org/10.1016/S0098-8472(02)00013-8

[55] Brunner, I. and Sperisen, C. (2013) Aluminum Exclusion and Aluminum Tolerance in Woody Plants. Frontiers in the Plant Science, 4, 172.

https://doi.org/10.3389/fpls.2013.00172

[56] Kochian, L.V., Piñeros, M.A., Liu, J. and Magalhaes, J.V. (2015) Plant Adaptation to Acid Soils: The Molecular Basis for Crop Aluminum Resistance. Annual Review of Plant of Biology, 66, 571-598.

https://doi.org/10.1146/annurev-arplant-043014-114822

[57] Carvalho, R.P., Moreira, R.A., Cruz, M.C.M., Fernandes, D.R. and Oliveira, A.F. (2014) Organomineral Fertilization on the Chemical Characteristics of Quartzarenic Neosol Cultivated with Olive Tree. Scientia Horticulturae, 176, 120-126. https://doi.org/10.1016/j.scienta.2014.07.006

[58] Rouphael, Y., Cardarelli, M. and Colla, G. (2015). Role of Arbuscular Mycorrhizal Fungi in Alleviating the Adverse Effects of Acidity and Aluminium Toxicity in Zucchini Squash. Scientia Horticulturae, 188, 97-105.

https://doi.org/10.1016/j.scienta.2015.03.031 